\title{
NODULAR HIDRADENOMA OF THE EYELID: AN UNUSUAL SITE OF PRESENTATION
}

Siva Ranjan D ${ }^{1}$, Vinay Kumar R², Rama Mohan Rao B ${ }^{3}$, Epari Sanjeeva Rao ${ }^{4}$, Shyamal K. Dwivedi ${ }^{5}$

\section{HOW TO CITE THIS ARTICLE:}

Siva Ranjan D, Vinay Kumar R, Rama Mohan Rao B, Epari Sanjeeva Rao, Shyamal K. Dwivedi. "Nodular hidradenoma of the eyelid: an unusual site of presentation". Journal of Evolution of Medical and Dental Sciences 2013; Vol. 2, Issue 41, October 14; Page: 7955-7958.

\begin{abstract}
Nodular hidradenoma is an uncommon benign skin adnexal neoplasm arising from eccrine sweat glands which typically involves the dermal layer of scalp, trunk, extremities and rarely on the eyelids. We report a rare case of nodular hidradenoma in an elderly female who presented with nodular swelling in the eyelid. Hidradenomas are unusual in the eyelids and the possibility of this variant should be considered in the differential diagnosis of eyelid tumors.
\end{abstract}

KEY WORDS: Nodular Hidradenoma, Eccrine sweat glands, Eyelid.

INTRODUCTION: Nodular hidradenoma $(\mathrm{NH})$ is a rare benign sweat gland tumor which is traditionally believed to originate from the eccrine gland. 1,2 While historically considered NH arises from eccrine glands, recent evidence suggest that it can be either apocrine or eccrine origin.3,4 Hidradenomas are slowly growing cutaneous neoplasm that can occur at various sites like head, trunk, extremities and extremely rare in eyelids. Sweat gland tumors of the eyelid are rare; yet the possibility of sweat gland tumors should be considered during differential diagnosis of eyelid tumors. We present a rare case of $\mathrm{NH}$ in an elderly female who presented with nodular swelling in the upper eyelid.

CASE REPORT: A 52 year old well oriented female patient presented to department of ophthalmology in our institute with a painless nodular mass in the right upper eyelid of three months duration. It was slow growing mass, patient complained of discomfort in the eye; otherwise normal. On examination it was firm to hard nodular mass measuring $2 \times 3$ centimeter $(\mathrm{cm})$ [Figure 1]. Squamous cell carcinoma, basal cell carcinoma and meibomian cell carcinoma were the differential diagnosis offered clinically. The nodular mass was excised and sent for histopathological examination. Specimen was fixed overnight in $10 \%$ formalin and histopathological processing was done.

Pathological findings: The excised specimen was skin covered, well encapsulated nodule measuring $3 \times 2 \times 1 \mathrm{~cm}$, the cut surface showed grey white solid areas with tiny cystic spaces. Microscopic sections studied stained with hematoxylin and eosin (H\&E) showed well circumscribed dermal tumor with cellular masses separated by collagenous stroma [Figure 2]. The tumor was made up of two type of cell population. The predominant type of cell was round to polyhedral with finely granular faintly eosinophilic cytoplasm having a round to oval nucleus and the second type having clear cytoplasm and small eccentric nucleus [Figure 3]. On the basis of histopathological examination, the diagnosis of nodular hidradenoma was made.

DISCUSSION: Nodular hidradenoma (NH) is also known as eccrine acrospiroma, clear cell hidradenoma and solid cystic hidradenoma. ${ }^{5} \mathrm{NH}$ is a benign tumor of skin appendages that arises 
from the distal excretory duct of eccrine sweat glands on the skin of head, face and upper extremities. Histologically, sweat glands may be either eccrine or apocrine in nature. Eccrine glands are present throughout the skin but are most abundant in the palms, soles, axilla, eyelid margins and in the surface dermis. Apocrine glands are found in relatively fewer regions of the body, mainly the axilla, around the nipples, the anogenital region and occasionally a small number on abdomen and chest. ${ }^{6}$ Liu in 1949 first described and termed it as eccrine acrospiroma, where spiroma means adenoma of sweat glands and acro means the top most or end. This tumor resembles the cells and structures of ductal segment of the eccrine sweat gland. ${ }^{1}$

$\mathrm{NH}$ is usually a single, slow growing, well circumscribed, round, mobile, cutaneous nodule ranging from $0.5 \mathrm{~cm}$ to $3 \mathrm{~cm}$ in diameter. ${ }^{1,8}$ Colour changes on skin surface, skin thickening, serous discharge or tenderness can accompany the lesion. ${ }^{2}$ In our case similarly it was single, slow growing lesion with reddish-pink discoloration of the skin surface measuring $3 \mathrm{~cm}$ in diameter; clinically there was no tenderness and discharge from the nodule. Histopathologically hidradenoma is composed of epithelial lobules within the dermis, showing tubular lumina lined by cuboidal or columnar cells with cystic spaces that contain faintly eosinophilic material. The solid component of the tumor is comprised of two types of cells, namely epidermoid cells which are round to polyhedral in shape with round to oval nuclei and glycogen rich clear cell with distinct boundaries and small eccentric nucleus. 9 similar histopathological findings were noted in our case.

Malignant hidradenoma had similarities to its benign counterpart but exhibits ulceration, brisk mitotic figures and an infiltrative growth pattern. These tumors in contrast to the benign forms tend to invade the surrounding tissue and have a high incidence of recurrence and distant metastasis. ${ }^{10}$ In our case clinically it appeared to be malignant but there was no palpable lymph node and on histopathological examination it was diagnosed as benign Nodular Hidradenoma.

The differential diagnosis includes primary skin tumors with follicular, sebaceous or sweat gland differentiation. Hidradenomas can mimic cutaneous metastatic disease from clear cell tumors such as renal cell carcinoma. ${ }^{11}$ Immunohistochemical analysis may become essential in distinguishing NH from its mimics that may include both benign and malignant lesions. Biernat et al showed cytokeratin expression in clear cell hidradenoma. Most keratin expression such as CK 6/18, CK 7 and CK8/18 was noted in squamous cells and tubule lining cells. Clear cells were consistently positive for epithelial membrane antigen and CK 10/17/18.11

To conclude nodular hidradenomas are distinctly unusual and extremely rare in the eyelids. The possibility of sweat gland tumors should be considered in the differential diagnosis of eyelid tumors to ensure early detection. Routine H\&E stained sections are usually sufficient for diagnosis and Immunohistochemical analysis is not required. Management involves complete excision of the lesion and recurrence is rare.

\section{REFERENCES:}

1. Mullaney PJ, Becker E, Graham B, Ghazarian D, Riddell RH, Salonen DC. Benign Hidradenoma: magnetic resonance and ultrasound features of two cases. Skeletal Radiol 2007; 36:1185-1190.

2. Ghai S, Bukhanov K. Eccrine acrospiroma of breast: mammographic and ultrasound findings. Clin Radiol. 2004; 59:1142-1144. 
3. Gianotti R, Alessi E (1997). Clear cell hidradenoma associated with the folliculo sebaceousapocrine unit. Histologic study of five cases. Am J Dermatopathol 19: 351-357.

4. McCalmont TH (1996). A call for logic in the classification of adnexal neoplasms. Am J Dermatopathol 18: 103-109.

5. Ahmed TS, Priore JD, Seykora JT. Tumors of the epidermal appendages. In: Elder DE, Elenitsas R, Murphy GF, Johnson BL, Xu X, editors. Lever's histopathology of the skin. $10^{\text {th }}$ edition. Philadelphia: Lippincott Williams and Wilkins; 2009. pp. 891-2.

6. Ahulwalia BK, Kurana AK, Chugh AD, Mhtani VG. Eccrine Spiradenoma of the eyelid: Case report. Br J Opthalmol. 1986; 70:580-3.

7. Bagga PK, Shahi M, Mahajan N. Clear cell hidradenoma: A case report. Internet J Pathol. 2009; 8:1528-8307.

8. Han YD, Huan Y, Deng JL, Zhang YG, Zhang CH. MRI appearance of multiple eccrine spiradenoma. Br J Radiol 2007; 80:27-9.

9. Pont RL. Eyelids and Lacrimal drainage system. In: Spencer WH, editor. Ophthalmic Pathology: An Atlas and Textbook. $3^{\text {rd }}$ ed. Philadelphia, PA: WD Saunders C; 1986. P.2214-28.

10. Liapakis IE, Korkolis DP, Koutsoumvi A, Fida A, Kokkalis G, Vassilopoulos PP. Malignant hidradenoma: A Report of Two Cases and Review of Literature. Anticancer Res. 2006; 26:2217-20.

11. Volmar KE, Cummings TJ, Wang WH, Creager AJ, Tyler DS, Xiehb. Clear cell hidradenoma: A mimic of metastatic clear cell tumors. Arch Pathol Lab Med.2005; 129:113- 6.

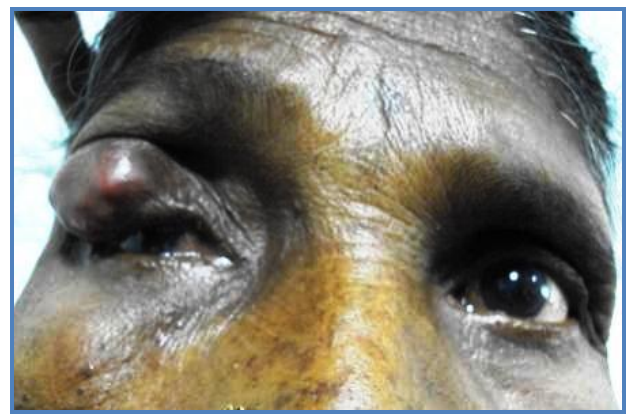

Figure 1: Swelling in the right upper eyelid

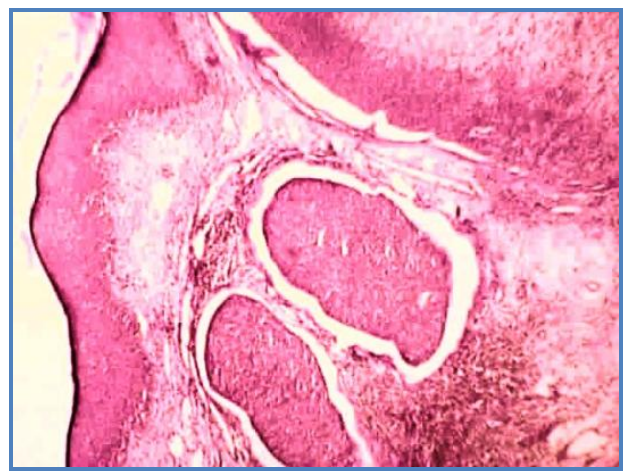

Figure 2: Islands of tumor cells separated by Collagenous stroma in dermis. (H\&E, x40) 


\section{CASE REPORT}

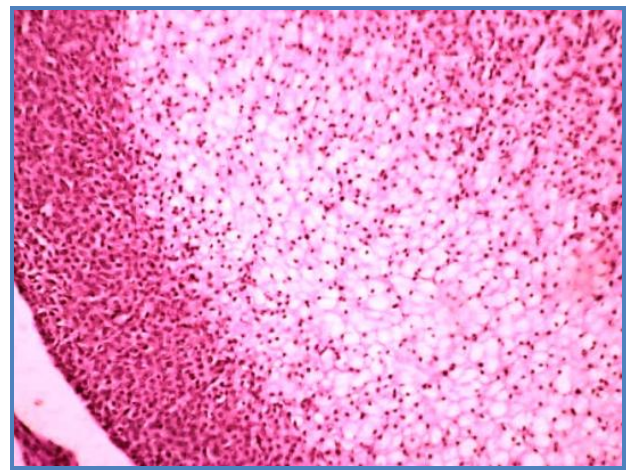

Figure 3: Two type of cell population: round to polyhedral cells and clear cells. (H\&E, x100)

\section{AUTHORS:}

1. Siva Ranjan D.

2. Vinay Kumar R.

3. Rama Mohan Rao B.

4. Epari Sanjeeva Rao

5. Shyamal K. Dwivedi

\section{PARTICULARS OF CONTRIBUTORS:}

1. Assistant Professor, Department of Pathology, Konaseema Institute of Medical Sciences and Research Foundation, Amalapuram.

2. Assistant Professor, Department of Pathology, Konaseema Institute of Medical Sciences and Research Foundation, Amalapuram.

3. Professor and HOD, Department of Pathology, Konaseema Institute of Medical Sciences and Research Foundation, Amalapuram.

4. Professor, Department of Pathology, Konaseema Institute of Medical Sciences and
5. V-R Fellow, Department of Opthalmology, Shankara Eye Care.

\section{NAME ADDRESS EMAIL ID OF THE CORRESPONDING AUTHOR:}

Dr. Siva Ranjan D.,

H.No. c-108, Phase - 2,

Hill Colony, Vanasthalipuram,

Hyderabad, 500070.

Email - avis.reddy@gmail.com

Date of Submission: 02/10/2013.

Date of Peer Review: 03/10/2013.

Date of Acceptance: 05/10/2013.

Date of Publishing: 10/10/2013 